\title{
Doubtful Threats and the Limits of Student Speech Rights
}

\author{
R. George Wright*
}

Public school authorities are charged with occasionally conflicting missions, including the promotion of academic learning, independent thought, personal responsibility, and a measure of orderliness. Conflicts among these values often take the form of what this Article refers to as "doubtful threats," in which the threat is reasonably judged, under the circumstances, to be unlikely to be carried out, and at a minimum to lack the element of imminence. Often, courts adjudicate such cases by finding a "substantial disruption" under Tinker. Among the Article's conclusions is that candor and transparency suggest that the courts should instead shift the focus in such cases from "disruption," as defined in Tinker, to something more akin to "distraction." While a focus on distraction is not endorsed by the language of Tinker, such a focus is both more accurately descriptive of the circumstances in many of the doubtful threat cases and at least equally faithful to a sensible balancing of the public schools' basic civic and educational missions.

\section{TABLE OF CONTENTS}

INTRODUCTION

I. STUDENT THREATS IN THE CONTEXT OF SUPREME COURT JURISPRUDENCE

II. THE TINKER DISRUPTION PRONG IN ACTION

A. The Tinker Disruption Prong: General Problems in Application.....

B. Some Doubtful Threat Cases: Making Do in the Absence of a Distraction Standard.

III. CONCENTRATING ON DISTRACTION: AN UNDERRECOGNIZED CONSIDERATION UNDER TINKER

* Lawrence A. Jegen Professor, Indiana University School of Law - Indianapolis. The author extends his thanks for their assistance to Rachel Anne Scherer and to the staff of the UC Davis Law Review. 
IV. Distractions FROM Distraction: AlternatiVE APPROACHES TO DOUBTFUL THREAT CASES............................. 709

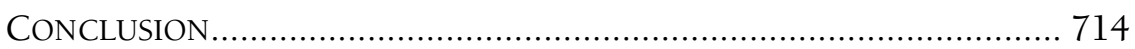




\section{INTRODUCTION}

Public schools are institutions with varied purposes. ${ }^{1}$ Although we as Americans may disagree over what those purposes are, we recognize their diversity. Of course, school administrators, boards of education, or the local voting public may not be subjectively aware of the public schools' various purposes or missions. This means that defining public schools' various missions is subject to abuse. ${ }^{2}$

Yet this potential to manipulate purposes should not mean that school speech law should ignore the widely acknowledged missions of the public schools. That would be a serious mistake. Even in an increasingly pluralist and globalized environment, public schools are "a principal instrument in awakening the child to cultural values, in preparing him for later professional training, and in helping him to adjust normally to his environment." ${ }^{3}$ Indeed, the public schools promote "the shared values of a civilized social order."

1 The language "basic educational mission" is quoted often in the context of student speech cases. See Hazelwood Sch. Dist. v. Kuhlmeier, 484 U.S. 260, 266 (1988) (quoting Bethel Sch. Dist. No. 403 v. Fraser, 478 U.S. 675, 685 (1986)); Porter v. Ascension Parish Sch. Bd., 393 F.3d 608, 615 n.16 (5th Cir. 2004) (quoting Hazelwood, 484 U.S. at 266); Canady v. Bossier Parish Sch. Bd., 240 F.3d 437, 441 (5th Cir. 2001) (quoting Hazelwood, 484 U.S. at 266); see also Brandt v. Bd. of Educ., 480 F.3d 460, 467 (7th Cir. 2007) (Posner, J., for the court) ("[W]e must not ignore the Supreme Court's admonition that 'a school need not tolerate student speech that is inconsistent with its basic educational mission."') (quoting Hazelwood, 484 U.S. at 266). But cf. Guiles ex rel. Guiles v. Marineau, 461 F.3d 320, 329 (2d Cir. 2006) ("[W]e decline to adopt the position of the Sixth Circuit in Boroff [v. Van Wert City Board of Educ., 220 F.3d 465, 470 (6th Cir. 2000),] that a school has broad authority under Fraser to prohibit speech that is inconsistent with its basic educational mission."'). For an explicit rejection of the view that any student speech interfering with a school's perceived educational mission can invariably be regulated on precisely that basis, see Morse v. Frederick, 127 S. Ct. 2618, 2637 (2007) (Alito, J., concurring) (noting possible ideological manipulability of nature and scope of 'educational mission,' and potential for speech repression therein).

2 See, e.g., Morse, 127 S. Ct. at 2637 (Alito, J., concurring) (noting that majority opinion does not allow school to censor any student speech that interferes with its "educational mission"); Guiles, 461 F.3d at 329-30 (holding that school may not censor student's expression merely because such expression conflicts with its "educational mission").

3 Hazelwood, 484 U.S. at 272 (quoting Brown v. Bd. of Educ., 347 U.S. 483, 493 (1954)); see, e.g., Doninger v. Niehoff, 514 F. Supp. 2d 199, 203 (D. Conn. 2007) (stating schools "must teach our children to think critically and to object to what they perceive as injustice ... [and] inculcate the values of civil discourse and respect for the dignity of every person").

4 Hazelwood, 484 U.S. at 272 (quoting Fraser, 478 U.S. at 683). For a discussion 
For the most part, public schools can promote the shared values of a civilized social order through their own official speech. They may do so through their curricula and through speech that bears or appears to bear official school approval. ${ }^{5}$ But part of learning these values is through self-expression, independent of any message promulgated through school speech. Teaching children how to exercise their free speech rights, and thereby promoting their maturation into good citizens, is itself among the basic purposes of public education. Learning to appreciate the role of free speech in our society requires not only study and preparation, but also practice. Through practice however, independent speech may give rise to disruption, physical disturbance, disorder, or infringement of others' rights. ${ }^{6}$

These potentially conflicting missions - promoting order and independent thought - present school administrators with difficult, often intractable problems. In difficult free speech situations, school administrators must rely not only on the judicial cases, but also on practical wisdom and closely informed judgment to determine what best suits their particular school's purposes. At the heart of this intersection lies student speech in the form of "doubtful threats."

A doubtful threat is a form of speech threatening future violence at a specific target. The target could be an individual, group, or institution. The point in the future may be ascertainable or unclear. At a minimum, doubtful threats evidence some intent to execute the threatened violence. Contrasted with more serious threats, however, doubtful threats usually lack imminence. Thus, doubtful threats differ from speech that presents a clear and imminent serious and specifically intended danger, as with the subversive advocacy cases dealt with under Brandenburg v. Ohio. ${ }^{7}$ Moreover, doubtful threats usually have accompanying evidence in the record that gives reason to doubt the speaker's intent to carry out the threat, no matter the substance of the speech itself. Although not always the case, these threats are often indirectly, or even inadvertently, conveyed to fellow students, teachers, or school administrators. Therefore, doubtful

of basic missions and the associated academic freedoms of the research university, see R. George Wright, The Emergence of First Amendment Academic Freedom, 86 NEB. L. REV. 793 (2007).

5 This qualification was central to Hazelwood, 484 U.S. at 271-72.

6 See Tinker v. Des Moines Indep. Cmty. Sch. Dist., 393 U.S. 503, 513-14 (1969). For commentary on Tinker, see, for example, Erwin Chemerinsky, Students Do Leave Their First Amendment Rights at the Schoolhouse Gates: What's Left of Tinker?, 48 DRAKE L. REV. 527, 530-35 (2000).

7 See 395 U.S. $444,447-48$ (1969). 
threats may also be contrasted with "true threats," as defined by Watts $v$. United States, ${ }^{8}$ which addresses speech that falls outside the scope of Brandenburg subversive advocacy yet which may still be proscribed. ${ }^{9}$ Thus, while the magnitude of a doubtful threat may be as great as a true threat, the probability of its occurrence is lower. This is, after all, what makes the threat doubtful.

In the school setting, these doubtful threats pose significant problems for students, teachers, and administrators. Doubtful threats may not be so severe as to disrupt school activities. Instead, they may introduce significant distractions into the learning environment, both for the target of the threat and others. This Article focuses on the

See 394 U.S. 705, 707-08 (1969).

9 See Virginia v. Black, 538 U.S. 343, 359 (2003) (stating “"[t]rue threats' encompass those statements where the speaker means to communicate a serious expression of an intent to commit an act of unlawful violence to a particular individual or group of individuals"); Watts, 394 U.S. at 707-08 (distinguishing, in light of context, true threat from offensively crude, expressly conditional political hyperbole, given national commitment to vehement and uninhibited debate and criticism of public officials and public figures over contentious public issues); Porter v. Ascension Parish Sch. Bd., 393 F.3d 608, 616 (5th Cir. 2004) (stating "[s]peech is a 'true threat' and therefore unprotected if an objectively reasonable person would interpret the speech as a 'serious expression of an intent to cause a present or future harm"”); Doe v. Pulaski County Special Sch. Dist., 306 F.3d 616, 622 (8th Cir. 2002) (noting split in circuits on whether to ask "whether a reasonable person standing in the shoes of the speaker would foresee that the recipient would perceive the statement as a threat, [or] ... . how a reasonable person standing in the recipient's shoes would view the alleged threat"); id. at 624 (noting requirement for "true threat" of knowing or intentional communication of threat, which may or may not be required under various Tinker analyses or under distraction analysis of doubtful threats advocated in this Article); United States v. Alkhabaz, 104 F.3d 1492, 1505 (6th Cir. 1997) (Krupansky, J., dissenting) (distinguishing "true threats" from "inadvertent statements, mistakes, jests, hyperbole, innocuous talk, or political commentary not objectively intended to express a real threat"); United States v. Barris, 46 F.3d 33, 35 (8th Cir. 1995) (per curiam) (finding true threat present where defendant "was highly agitated and repeatedly threatened to kill the President - even after Secret Service agents had interviewed him following the initial threats," and where defendant "stated that he had access to a cache of weapons"); Citizen Publ'g Co. v. Miller, 115 P.3d 107, 114 (Ariz. 2005) (en banc) (noting that "the speaker need not actually intend to carry out the threat" (quoting Black, 538 U.S. at 359-60)); see also id. (noting that while Watts interpreted particular federal criminal statute, First Amendment does set limits on criminal prosecution of pure speech) (citing Watts, 394 U.S. at 707). For a provocative and broad assertion in this context, see People v. Stanley, 170 P.3d 782, 788 (Colo. App. 2007). For a discussion of the intent requirement in the "true threat" context, see Paul T. Crane, Note, "True Threats" and the Issue of Intent, 92 VA. L. REV. $1225,1227-29$ (2006). 
problem of distraction and where it fits, or should fit, within current student free speech jurisprudence.

In a phrase, substantial disruption is not substantial distraction. Disruption, perhaps in the form of an assault, tumult, brawl, physical confrontation, or a classic altercation involving individuals or groups, may certainly also be distracting. Crucially though, some forms of substantial distraction may be at least as inconsistent with the basic purposes and missions of the school as are substantial disruptions. Of course, doubtful threats are not the only source of distractions. This is readily apparent to those familiar with cell phones, Internet access, iPods ${ }^{\circledR}$, doodle pads, or other forms of high and low technology. ${ }^{10}$ These distractions are voluntary or self-imposed. But doubtful threats generate distractions that are not voluntarily created or welcomed. This category of distractive effects is not educationally trivial, especially from the target's standpoint. Furthermore, doubtful threats not only affect the target but also influence other students' performance, teacher competence, and the ability of administrators to run schools smoothly. They impose substantial costs.

Despite these costs, current United States Supreme Court jurisprudence in the area of student free speech does not account for the substantial distractions that doubtful threats may pose. In its most famous case in this area, Tinker v. Des Moines Independent Community School District, ${ }^{11}$ the Court gave administrators the ability to restrict student speech that poses a substantial disruption or infringes upon the rights of others. ${ }^{12}$ But neither Tinker nor any of the Supreme Court's other school speech cases is sufficiently sensitive to the more subtle, less overt, more psychological, more indirect, and often longterm, distractive effects of doubtful threats. ${ }^{13}$

The category of doubtful threats is important not only in its own right, but also for exposing the limits of the Tinker disruption prong. Tinker may be read to rigorously protect student speech. But Tinker does not easily fit into modern forum analysis applied outside of school settings. Under a forum analysis, the speech at stake in doubtful threats is subject to countervailing considerations. Doubtful threats are most often restricted through content-based regulations legal restrictions crafted on the basis of what the speaker says rather

10 See R. George Wright, Tinker and Student Free Speech Rights, 41 IND. L. REV. 105, 128-31 (2008).

11393 U.S. 503 (1969).

12 Id. at 512-13.

13 See infra Parts III-IV. 
than how the speaker says it. ${ }^{14}$ Under forum analysis, content-based regulations are subject to more searching judicial review. But forum analysis also requires courts to consider the nature of the speech. Most doubtful threat cases do not involve what may be recognized as political speech - speech on a public issue, interest, or concern and instead involve speech of less social utility. ${ }^{15}$ This factor weighs against rigorous speech protection. When these two aspects of forum analysis are applied, we see that the Tinker test may call for a more rigorous standard in light of the modest speech values at stake.

This Article examines the role that distractive effects do and should play in evaluating doubtful threat cases. Part I maps Supreme Court jurisprudence in the area of student free speech, starting with Tinker and concluding with its most recent decision in Morse v. Frederick. ${ }^{16}$ Part II examines, through the use of representative cases, how lower courts have applied that student free speech law to a variety of doubtful threat scenarios. As we will see, something more than substantial disruption under Tinker motivates courts' justifications for the results in these cases. Part III then sets forth the argument for introducing the concept of substantial distraction as a justification for administrative responses to doubtful threats. I argue that neither of Tinker's prongs sufficiently addresses the distractive effects of doubtful threats. Furthermore, in light of the substantial costs and few corresponding benefits of threatening speech, a distractive effects analysis is a valid justification for infringing on student speech. Part IV addresses alternatives to regulating doubtful threats on a supposedly content-neutral basis, whether by incorporating a distraction analysis into student free speech analysis or otherwise. As I argue, the most obvious remaining alternative reforms are limited in value, or at least equally subject to challenge.

14 For a skeptical look at the distinction between content-based and contentneutral restriction of speech, see generally R. George Wright, Content-Based and Content-Neutral Regulation of Speech: The Limitations of a Common Distinction, $60 \mathrm{U}$. Miami L. Rev. 333 (2006).

15 For a sampling of recent doubtful threat cases, see infra Part II.B. For the most recent Supreme Court jurisprudence on the distinction between speech that does or does not discuss a matter of public interest or concern, see Garcetti v. Ceballos, 547 U.S. 410, 410-11 (2006).

$16 \quad 127$ S. Ct. 2618 (2007). 


\section{STUdENT THREATS IN THE CONTEXT OF SUPREME COURT JURISPRUDENCE}

To understand why lower courts have trouble with doubtful threats cases, it is helpful to review Supreme Court jurisprudence regarding the limits of student free speech rights. This Part briefly traces the evolution of this body of law, beginning with the wellspring of modern student free speech analysis, Tinker $v$. Des Moines Independent Community School District, ${ }^{17}$ through the Court's latest decision in Morse v. Frederick. ${ }^{18}$ At the end of this journey, we see that none of these cases adequately addresses threats in the student context. Moreover, none provides a solid foundation for the distraction analysis I introduce in this Article.

Any analysis of modern free speech analysis in the school context must begin with Tinker. The facts of Tinker are well known. A number of schoolchildren wore black armbands to school in protest of the Vietnam War. ${ }^{19}$ Alerted to the planned protest, school officials banned the armbands. ${ }^{20}$ When the students showed up to school, authorities ordered them to remove the bands; when the students refused, the school suspended them. ${ }^{21}$ The students sued these authorities, claiming a violation of their First Amendment rights. ${ }^{22}$

In now famous words, the Court noted that "students [and] teachers [do not] shed their constitutional rights to freedom of speech or expression at the schoolhouse gate." ${ }^{23}$ The Court set forth a twopronged test, determining that a school may silence a student speaker when his speech does or is reasonably forecasted to: (1) materially and substantially disrupt the work and discipline of the school, or (2) infringe upon the rights of others. ${ }^{24}$ I refer to these prongs in this

393 U.S. 503 (1969).

127 S. Ct. 2618 (2007)

19 Tinker, 393 U.S. at 504.

20 Id.

21 Id.

22 Id.

23 Id. at 506.

24 Id. at 512-13. As courts have noted, Tinker formulated these standards in different ways throughout the opinion. In Wisniewski v. Board of Education, $494 \mathrm{~F} .3 \mathrm{~d}$ 34 (2d Cir. 2007), the court highlighted four different formulations of the Tinker prongs:

The Court used several formulations to describe student conduct . . that (1) "would substantially interfere with the work of the school," or (2) would cause "material and substantial interference with schoolwork or discipline," 
Article as Tinker's disruption and rights prongs, respectively. Applying this standard to the facts of Tinker, the Court found that the students neither interrupted school activities nor interfered with the rights of others. ${ }^{25}$ At most they prompted discussion outside of the classrooms but did not cause disorder. ${ }^{26}$ As such, the Court found that the school's reaction violated the students' First Amendment rights.

While Tinker most naturally applied to content-based regulations of political speech, this left open the question of students' First Amendment rights when with regard to indecent speech. The Court addressed indecent speech in Bethel School District No. 403 v. Fraser. ${ }^{27}$ In Fraser, a student, Matthew Fraser, gave a speech nominating one of his classmates for student government at a student assembly. Fraser had discussed the contents of his speech with two teachers, both of whom warned against delivering it. Undeterred, he delivered the speech, which the Court described as an "elaborate, graphic, and explicit sexual metaphor." 28 The school suspended him for three days and removed him from contention to serve as a graduation speaker at

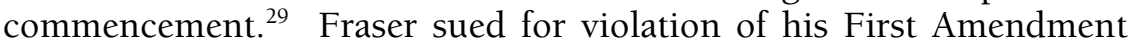
rights under Tinker.

The Court disagreed with him. It held that the First Amendment does not prevent school officials from preventing or punishing "lewd," "indecent," "vulgar," or "plainly offensive" speech that undermines a school's fundamental values or its basic educational mission. ${ }^{30}$ The Court distinguished Fraser's speech from that at issue in Tinker, which

or (3) "would materially and substantially disrupt the work and discipline of the school," or (4) "might reasonably have led school authorities to forecast substantial disruption of or material interference with school activities . ..."

Wisniewski, 494 F.3d at 38 (citations omitted).

In Morse, the Supreme Court endorsed Tinker's third formulation as the holding. Morse v. Frederick, 127 S. Ct. 2618, 2625-26 (2007); see also Wisniewski, 494 F.3d at 38. I have merged the forecasting aspect highlighted in the fourth formulation into the two prongs. This reflects the fact that the speech containing doubtful threats is rarely ever, by itself, likely to implicate either prong. Rather, the potential for the speaker to execute the underlying action contained in the threat is what is likely to cause substantial disruption or infringement of rights. Addressing the severity of the threat intrinsically relies upon forecasting.

25 Tinker, 393 U.S. at 514.

26 Id.

27478 U.S. 675 (1986).

28 Id. at $677-78$.

29 Id. at 678.

30 Id. at $685-86$. 
expressed a clear political viewpoint. Clearly, some form of content discrimination was permissible in the Court's eyes to uphold what it viewed as the school's mission. The Court did not define, however, the meanings of lewd or vulgar, and most importantly in the context of doubtful threats cases, indecent or plainly offensive. ${ }^{31}$

Fraser left open the question of the degree to which school-sponsored speech could conflict with a student's First Amendment rights. The Court addressed that question in Hazelwood School District v. Kuhlmeier. ${ }^{32}$ Hazelwood involved a school principal's decision not to print two articles in the school newspaper. ${ }^{33}$ One of the articles addressed students' struggles with teen pregnancy; the other addressed the impact of divorce on students' lives. ${ }^{34}$ These articles were the product of students taking part in a Journalism class. ${ }^{35}$ The school and local school board set the curriculum and funded the class. ${ }^{36}$ The students whose articles were excised sued the school for violating their right to free speech.

The Court concluded again that Tinker's standard did not apply. This time it held that Tinker does not apply when a school decides not to "lend its name and resources to the dissemination of student expression." 37 In other words, school-sponsored speech that might reasonably be viewed as bearing the imprimatur of the school differed from punishment of student speech in Tinker and Fraser. Moreover, the Court held that school authorities do not violate the First Amendment by "exercising editorial control over the style and content of student speech in school-sponsored expressive activities so long as their actions are reasonably related to legitimate pedagogical concerns." 38 Applying this standard, the Court found the principal

31 The Supreme Court has since addressed the scope of these terms. In Morse v. Frederick, Justice Roberts refused to extend Fraser to hold that the speech at issue in the case - speech reasonably endorsing drug use - was offensive. Morse $v$. Frederick, 127 S. Ct. 2618, 2629 (2007) ("We think this stretches Fraser too far; that case should not be read to encompass any speech that could fit under some definition of 'offensive.' After all, much political and religious speech might be perceived as offensive to some."). Whether this forecloses all avenues for treating doubtful threats as offensive is unclear.

32484 U.S. 260 (1988).

33 Id. at 264.

34 Id. at 263.

35 Id. at 262.

36 Id. at 262-63.

37 Id. at $272-73$.

38 Id. at 273. 
acted reasonably under the circumstances and did not violate the students' First Amendment rights. ${ }^{39}$

Hazelwood may have created more questions than it answered. For the purposes of doubtful threats cases, however, it is worth focusing on the limits of school-sponsored speech. For example, can student works containing threats but written as part of a class assignment be construed as inconsistent with school-sponsored speech endorsing physical safety and peace? At the outer limits of Hazelwood, we may be able to analogize these student writings to the articles excised from the student newspaper and argue they conflict with school-sponsored speech. No matter the merits of this argument, we again see the difficulty in fitting doubtful threats cases into Supreme Court jurisprudence.

Finally, we turn to the Court's most recent decision in the area of student free speech rights, Morse v. Frederick. ${ }^{40}$ In Morse, a student, Joseph Frederick, displayed a banner containing the words "BONG HiTS 4 JESUS" as the Olympic torch paraded past his school in Juneau, Alaska. ${ }^{41}$ The school's principal had permitted students to leave class to watch the procession, with school authorities monitoring students. ${ }^{42}$ When the principal saw Frederick's banner, she instructed him to take it down. ${ }^{43}$ He refused and the principal took it down herself, stating later that she thought it encouraged illegal drug use. ${ }^{44}$ She then suspended Frederick for ten days. ${ }^{45}$ Frederick filed suit in federal court against the principal and school board, alleging their actions violated his First Amendment rights.

The Court disagreed and upheld the principal's actions. Justice Roberts's majority opinion held that school authorities may restrict student speech that is "reasonably viewed as promoting illegal drug use." ${ }^{46}$ According to the Court, Tinker and its disruption prong did not apply. ${ }^{47}$ Rather, the school's interest in deterring drug use is so compelling that it outweighs any countervailing right to freely express speech advocating just the opposite. ${ }^{48}$

\footnotetext{
39 Id. at 274.

40127 S. Ct. 2618 (2007).

${ }^{41}$ Id. at 2622.

42 Id.

43 Id.

44 Id. at 2622-23.

45 Id. at 2622.

46 Id. at 2625.

47 Id. at 2627.

48 Id. at 2628-29.
} 
In an important concurrence for our purposes, Justice Alito wrote to clarify his views. His opinion makes clear that the First Amendment does not permit public school officials to "censor any student speech that interferes with a school's 'educational mission." 49 Such a standard would be easily manipulated to allow content or viewpoint discrimination of the type explicitly forbidden in Tinker. ${ }^{50}$ Rather, any infringement of student speech must be based on the special characteristics of a school, notably protecting students from threats to their physical safety. ${ }^{51}$ In Justice Alito's view, speech advocating drug use imperils student safety and justified the principal's actions.

Justice Alito's concurrence comes the closest to addressing the problem of doubtful threats. Threats aimed at students or teachers clearly implicate their physical safety. But the facts of Morse are not directly on point. It may be that Frederick's speech threatened the physical safety of students by encouraging them to use drugs. But Frederick's speech was not a threat itself. The Supreme Court's failure to address cases that directly involve threats, and the appropriate administrative responses to them, has left the lower courts with little guidance. To find their way, some courts have turned to the Court's decisions addressing threats outside of the school setting. For example, the Eighth and Ninth Circuits have held the Court's opinion in Watts $v$. United States ${ }^{52}$ not Tinker, governs student threats. ${ }^{53}$ Other courts, such as the Second Circuit, have refused to extend Watts to student threats and instead rely on Tinker. ${ }^{54}$ No matter the approach, the point here is simply that despite four prominent Supreme Court cases on student speech, the lower courts continue to attempt to

49 Id. at 2637 (Alito, J., concurring)

50 Id.

51 Id. at 2638.

52394 U.S. 705 (1969). Watts held that the First Amendment does not protect "true threats," but failed to set a standard for determining what speech does or does not constitute a true threat. Id. at 707-08. The appellate courts have held that a true threat is a threat that a reasonable person would interpret as a serious expression of an intent to cause a present or future harm. See United States v. Fulmer, 108 F.3d 1486, 1490-91 (1st Cir. 1997) (describing differing approaches among the circuits to defining true threats); see also Doe v. Pulaski County Special Sch. Dist., 306 F.3d 616, 621-22 (8th Cir. 2002) (en banc).

53 Doe, 306 F.3d at 621-27; Lovell v. Poway Unified Sch. Dist., 90 F.3d 367, 37173 (9th Cir. 1996). But see Wisniewski v. Bd. of Educ., 494 F.3d 34, 38 (2d Cir. 2007) (holding that Tinker, providing broader authority to sanction student speech, applies and not Watts).

54 See, e.g., Wisniewski, 494 F.3d at 38 (refusing to apply Watts to school setting). 
squeeze doubtful threat cases into an ill-suited legal framework. As the next Part shows, the results are less than compelling.

\section{The TINKER DisRUPtion PRONG IN ACTION}

We have seen that Supreme Court jurisprudence on student free speech, in particular Tinker, has left many holes for lower courts to fill. Unsurprisingly, these courts have interpreted Tinker differently. Some courts have interpreted Tinker as giving strong protection to student speech; others have drawn just the opposite conclusion. Moreover, courts have manipulated Tinker or missed its teachings altogether. Subpart A first explores the strengths and weaknesses of the Tinker test. Subpart B then explores cases that apply Tinker to doubtful threats. This exploration reveals the difficulties of applying Tinker to doubtful threats.

As discussed in Part I, Tinker's disruption prong requires a reasonable fear of substantial disruption, including physical disturbance, disorder, or interference with appropriate school discipline. ${ }^{55}$ This legitimate fear may be contrasted with restrictions of speech by authorities based merely on an "undifferentiated fear or apprehension" of such a disturbance. ${ }^{56}$ Inevitably, the line between "undifferentiated" and "differentiated" fears of disruption will be subjective to some degree. Among other considerations, a court's willingness to defer to the judgment of school officials will play a role. Courts can be more or less swayed by the experience or apparent partisanship school officials, the degree of democratic accountability, and unexplainable nuances of local school and community culture. ${ }^{57}$

In light of these many considerations, we should hardly be surprised when courts give Tinker's disruption prong stronger or weaker interpretations. School contexts vary, and one official's correct intuition about school culture, though not provable in court, may appear to be rank repressiveness to another. The Tinker disruption prong's adaptability is the other side of its vulnerability to arbitrariness and manipulation. Because we need the test's current adaptability, we must therefore accept some degree of manipulability by both school officials

55 See Tinker v. Des Moines Indep. Cmty. Sch. Dist., 393 U.S. 503, 508, 509, $513-$ 14 (1969).

56 Id. at 508.

57 See, e.g., Scott v. Sch. Bd., 324 F.3d 1246, 1248 (11th Cir. 2003) (per curiam) (finding that school must have certain flexibility to control contours of student expression within its property). 
and courts. As we shall see, however, Tinker's disruption prong does not ask the right question when it comes to doubtful threat or distraction cases. That, and not its manipulability, is its principal flaw.

\section{A. The Tinker Disruption Prong: General Problems in Application}

The vast majority of student speech cases, and there are many of them, focus on Tinker's disruption prong. A brief analysis of two representative cases illustrates the strengths, limits, and the occasional misdirection of the Tinker disruption inquiry. The first case, Scott $v$. School Board ${ }^{58}$ is representative of an entire subcategory of Tinker disruption that cases involve the wearing, displaying, or drawing of the Confederate flag or related symbols. ${ }^{59}$ The second case, Newsom ex rel. Newsom v. Albemarle County School Board, ${ }^{60}$ explores the application of Tinker's disruption prong to school dress codes. Both cases underscore the problems with the disruption prong.

In Scott, two students brought Confederate flags onto school premises. ${ }^{61}$ The principal, after having warned the students not to do so, suspended them. ${ }^{62}$ The Eleventh Circuit, quoting verbatim from the district court's order, upheld the principal's decision to ban the flag from school premises. In large measure, these courts based their decisions on evidence presented by school officials that racial tension and racially based fights precipitated the display of the flag. ${ }^{63}$ In a rather conclusory fashion, the court held that the principal "did nothing wrong" under Tinker. ${ }^{64}$ More interestingly, perhaps, the court devoted more time to its analysis of Fraser. It cited language from Fraser, arguably beyond the scope of its holding, to the effect that "even if disruption is not immediately likely, school officials are charged with the duty to inculcate the habits and manners of civility as values conducive both to happiness and to the practice of self-

\footnotetext{
58 Scott, 324 F.3d 1246.

59 See R. George Wright, Dignity and Conflict of Constitutional Values: The Case of Free Speech and Equal Protection, 43 SAN DIEGO L. REV. 527, 569-74 (2006) [hereinafter Wright, Dignity and Conflict]; R. George Wright, School-Sponsored Speech and the Surprising Case for Viewpoint-Based Regulations, 31 S. ILL. U. L.J. 175, 202 n.160 (2007) [hereinafter Wright, School-Sponsored Speech].

60354 F.3d 249 (4th Cir. 2003).

61 Scott, 324 F.3d at 1247.

62 Id.

63 Id. at 1249 (citing, inter alia, Denno v. Sch. Bd., 218 F.3d 1267 (11th Cir. 2000)).

64 Id.
} 
government." "65 The court went on to assess whether the Confederate flag is offensive within the meaning of Fraser. Although never explicitly making that conclusion, the court upheld the principal's action under Fraser. In support of its holding, the court noted that part of the public schools' mission is to teach students of diverse backgrounds to interact with each other in civilized ways. ${ }^{66}$

Whether or not Scott's application of Fraser is appropriate, or whether the court should have applied a more rigorous Tinker analysis to the clear political speech at issue ${ }^{67}$ Scott illustrates that the Tinker disruption prong, even in conjunction with the rights prong, may not always capture the practical experience of the public schools. ${ }^{68}$ After all, the Scott court ultimately retreated from its Tinker analysis, instead choosing to defer to a contextualized administrative judgment based in part on pedagogical concerns beyond disruption. At least some of the courts addressing the Confederate flag prohibitions seem, for whatever reason, skittish about resting the full weight of the outcome on Tinker's disruption analysis. ${ }^{69}$ It is possible that courts sense that

65 Id. at 1248 (quoting Bethel Sch. Dist. No. 403 v. Fraser, 478 U.S. 675, 683 (1986)).

66 Id. at 1249 ("[A] public school's essential mission must be to teach students of differing races, creeds and colors to engage each other in civil terms rather than in 'terms of debate highly offensive or highly threatening to others."').

67 It is worthwhile to note the restriction on the speech in question despite its apparent political content, in contrast with a number of doubtful threat cases. See, e.g., West v. Derby Unified Sch. Dist. No. 260, 206 F.3d 1358, 1367 (10th Cir. 2000). In West the Tenth Circuit concluded, based on evidence of recent racial altercations, racial graffiti, and general racial tension, that a suspension for drawing a Confederate flag on notebook paper was justified, given the "reasonable basis for forecasting disruption from display of such items at school." Id. at 1366. Here again, as in Scott, the court did not entirely confine its discussion to the Tinker disruption prong. The court noted, in particular, that the school "had reason to believe that a student's display of the Confederate flag might cause disruption and interfere with the rights of other students to be secure and let alone." Id. Again, our point is not that the court in West was or was not over-extending the Tinker rights prong. Instead, our interest is in the court's almost subliminal sense that the Tinker disruption prong should not in this case exhaust the analysis. Whether this court, or any other court, consciously takes the Tinker disruption prong to be sometimes inadequate on its own terms, as we suggest, or instead wishes merely to justify the judicial outcome on multiple grounds, must be left to speculation.

68 The Eleventh Circuit noted that "one only needs to consult the evening news to understand the concern school administrators ha[ve] regarding the disruption, hurt feelings, emotional trauma and outright violence[,] which the display of the symbols involved in this case could provoke." Scott, 324 F.3d at 1249.

69 See supra notes 61-66 and accompanying text. 
not every instance of behavior amounting to substantial distraction will also qualify as disruption under Tinker.

The Tinker disruption standard is of course employed in a wide range of other contexts. For example, in Newsom, a student brought an overbreadth challenge to a school's dress code policy, which prohibited clothing depicting messages relating to weapons. ${ }^{70}$ The district court denied a preliminary injunction but the Fourth Circuit reversed, finding the school dress code violated the First Amendment. ${ }^{71}$ The court based its decision largely on a lack of disruption under Tinker. $^{72}$ The court noted the absence of any evidence that the proscribed messages had ever "substantially disrupted school operations or interfered with the rights of others." 73 The court pointed in particular to the lack of evidence that any such messages "ever caused a commotion or was going to cause one" at the school in question, inferring that the prohibition was "not necessary to maintain order and discipline" at the school. ${ }^{74}$

My objective here is not to question the results in these cases. At this point, I merely raise the possibility that some cases, including cases inapt for resolution on any other currently recognized school speech theory, may not be best handled by inquiring into the presence or likelihood of "commotion," or of impairment of "order and discipline" at the school. As Subpart B makes evident, a model based on these inquiries simply may not fit the distractive effects in many doubtful threat cases. ${ }^{75}$

70 Newsom ex rel. Newsom v. Albemarle County Sch. Bd., 354 F.3d 249, 252 (4th Cir. 2003).

71 Id.

72 Id. at 259. The prohibition on weapons-related messages on clothing and other items was only part of a broader ban on messages that relate to "drugs, alcohol, tobacco, weapons, violence, sex, vulgarity, or that reflect adversely upon persons because of their race or ethnic group." Id.

73 Id.

74 Id.

75 Consider also the recent case of Layshock v. Hermitage School District, 496 F. Supp. 2d 587 (W.D. Pa. 2007). Layshock involved one among several Internet profiles created by students, including the plaintiff student's arguably vulgar Internet parody of the school principal. Questions of causation, among other issues, were relevant to the case. Id. at 600. Speech that is neither disruptive nor, on our analysis, distracting, should not be made punishable merely because the official investigation into such speech itself unnecessarily caused such disruption or distraction. In Layshock, there was some uncontested evidence of what might broadly be called at least temporary or mild disruption. Id. at 592-93. But the court concluded as a matter of law that "the actual disruption was rather minimal - no classes were cancelled, no widespread disorder occurred, there was no violence or student 


\section{B. Some Doubtful Threat Cases: Making Do in the Absence of a Distraction Standard}

Recent violence within public schools, including instances of mass murder, has forced school authorities to take proactive approaches to student threats of violence. Recognizing the problems this violence poses to the educational mission of public schools, federal courts have often sided with administrative crackdowns on speech threatening violence. I do not necessarily quarrel with the ultimate decisions in these cases. ${ }^{76}$ Rather, I take issue with their reasoning. As this Subpart makes evident, most courts upholding administrative responses to threats of violence have relied upon Tinker's substantial disruption prong to do so. These courts have extended Tinker to characterize these doubtful threats as likely to pose a substantial risk of disruption to the educational mission of the schools. Yet as I show, if these threats truly pose a risk of substantial disruption, the solutions administrators propose to neutralize them are wholly inadequate to address the problem. Rather, these administrative responses suggest the student threats pose more of a distraction than a disruption. The rationale undergirding these decisions should then be based on a distraction, not disruption, analysis. Thus, instead of forcing lower courts to justify these administrative responses under Tinker's disruption analysis, I argue the Supreme Court should revise this doctrinal area to accommodate the reality that distraction can frustrate educational missions and purposes as much as disruption.

A review of recent appellate cases addressing doubtful threats reveals two types of threats: (1) generalized threats aimed at a class, the student body at large, or multiple schools within the district, and (2) specialized threats aimed at particular parties, such as teachers. One might expect the administrative responses in theses cases to differ depending on the nature of the threat. Yet as we will see, the response is almost uniformly the same: suspension. But even assuming that suspension is the appropriate response, the justification for these suspensions, and the corresponding invasion of the student's free speech, cannot rest solely on a disruption rationale.

disciplinary action." Id. at 600 . For a case in some respects factually similar, but with more severe reaction, including a teacher's inability to finish the school year despite the student website's falling short of a "true threat," see J.S. ex rel. H.S. v. Bethlehem Area School District, 807 A.2d 842, 859-60 (Pa. 2002).

76 Cf. Douglas Lee, Fifth Circuit Extends Limits on Student Speech (Nov. 27, 2007), www.firstamendmentcenter.org/commentary.aspx?id=19363 (last visited Jan. 9, 2009) (criticizing Ponce v. Socorro Indep. Sch. Dist., 508 F.3d 765 (5th Cir. 2007)). 
Two appellate cases reveal the federal courts' general approach to assessing and adjudicating threats aimed at classes or schools. In LaVine v. Blaine School District, ${ }^{77}$ decided before Morse v. Frederick, an eleventhgrade student wrote a nonpolitical poem entitled "Last Words." ${ }^{78}$ This poem referred in part to the student's planned suicide as well as to the classroom shooting of twenty-eight otherwise unspecified students, set two years in the past. ${ }^{79}$ The writer had previously discussed thoughts about suicide with the school psychologist. ${ }^{80}$ The writer showed the poem in question first to his mother and then, after setting it aside for several months, to several school friends. ${ }^{81}$ Finally, the student asked his teacher to review the work. ${ }^{82}$ She read it and immediately expressed her concern to school officials. ${ }^{83}$

These school officials turned to the local police and a psychiatrist to determine the next best steps. Based on an interview with the student at his home, a police officer determined that he did not have probable cause to involuntarily commit the student. ${ }^{84}$ After the psychiatrist conferred with the police officer, he also determined that he could not legally commit the student under state law. ${ }^{85}$ The school, however, did take action. Given that the note contemplated both the student's suicide and a Columbine-style attack, the school temporarily suspended the student for seventeen days, pending a psychiatric evaluation. ${ }^{86}$ After this period, the student returned to school without further incident. ${ }^{87}$ The student challenged the suspension as violating his First Amendment free speech rights. The school's theory, endorsed on appeal, was that his work posed a risk of substantial disruption under Tinker. ${ }^{88}$

In analyzing LaVine's reasoning, we need not assess the likelihood that the student's notebook or the threatened actions therein would cause any actual disruption, physical disturbance, or disorder. For our

257 F.3d 981 (9th Cir. 2001).

78 Id. at $983-84$.

79 Id.

80 Id. at 984.

81 Id.

82 Id.

83 Id.

84 Id. at 985.

85 Id.

86 Id. at 986.

87 Id.

88 Id. at 990. 
purposes, we can assume that there was in fact a likelihood of substantial disruption. Rather, assuming this to be the case, we should ask whether the court's rationale in fact justifies the administrative responses to the threat. If it does not, we might then ask whether a distraction rationale better explains the administrators' approaches to neutralizing the threat.

If the main concern in such a case is future disruption, violence, or disorder, then the most effective but perhaps most severe approach would be physical confinement beyond the school's jurisdiction. No one can dispute that confinement makes such a disruption physically impossible. But even assuming physical confinement is not an option or appropriate, a logical approach would focus on close supervision by school authorities and the student's parents, psychiatric and psychological testing, continued monitoring, and perhaps mandatory though nonpunitive counseling. Even directly confronting the writer and explicitly discussing the immediate consequences of any illegal or disruptive act may have preventive value. To effectively neutralize the risk of substantial disruption, the administrative response need not be punitive or involve a formal, public penalty for engaging in objectionable speech. ${ }^{89}$

But in LaVine, there was little connection between the perceived severity of the threat and the administrative action. The actual penalty of suspending the student for a little over two weeks does not seem to match a sufficient concern for genuine disruption. If the school officials in LaVine had really believed and been motivated by a fear of disruption, the brief suspension could have potentially exacerbated the writer's sense of grievance, frustration, alienation, and resolve. ${ }^{90}$ Stated differently, if the student's threat were truly credible, suspension would have been ineffective to deter a school shooting. In light of Columbine and similar shootings, suspension might be justified as an exercise of an abundance of caution immediately after learning of the notebook. But does the Tinker disruption rationale explain the school authorities' longterm resolution to the LaVine problem?

89 See, e.g., Vernonia Sch. Dist. 47J v. Acton, 515 U.S. 646 (1995) (detailing nonpunitive responses to drug issues).

90 In fact, the court readily acknowledged this problem. It pointed to a recent incident at a school in Springfield, Oregon, in which a student, Kip Kinkel, was suspended for possessing a handgun, went home, murdered his parents, then returned the next day to school, killing two more students and wounding 24. LaVine, 257 F.3d at 990 n.7; Laurie Goodstein \& William Glaberson, The Well-Marked Roads to Homicidal Rage, N.Y. TIMES, Apr. 10, 2000, http://query.nytimes.com/gst/fullpage.html?res= 990DE3DD173EF933A25757C0A9669C8B63\&sec=health\&spon=\&partner=permalink \&exprod=permalink. 
The answer to this question is almost certainly no. Rather, what the general physical absence of the writer from the school is more likely to do is to reduce distraction. School officials, teachers, and fellow students in general will avoid having daily reminders of the threat. Teachers will be able to focus on their classrooms, students on their class work, and administrators on running the school. Of course, I do not suggest that once the writer is out of sight, he is entirely out of mind. But with his continuing physical absence, one might expect anxiety and distraction to gradually subside over time. ${ }^{91}$ It may be that the punishment in LaVine was the equivalent of a "zero tolerance" policy for the kind of speech in question. But even assuming that to be true, the penalty imposed and upheld in LaVine makes more sense on a distraction rationale than on a disruption rationale. ${ }^{92}$

After the Supreme Court's decision in Morse, other courts have employed similar rationales to conclude that the First Amendment does not protect threats aimed at classes or schools. In Ponce v. Socorro Independent School District, ${ }^{93}$ a student kept a notebook diary, which he and his mother claimed was a work of ongoing fiction. ${ }^{94}$ The notebook is clearly a troubled and troubling work. It details Ponce's involvement in a pseudo-Nazi group, which, at Ponce's instigation, had physically injured designated minority groups, giving at least some political element to the student's speech. ${ }^{95}$ More importantly for our purposes, the notebook describes a coordinated simultaneous shooting on various local schools, or else a "Columbine shooting" attack on the writer's own

91 The residual potential for distraction certainly remains because the possibility, however great or remote, of the writer's unauthorized and perhaps substantially disruptive physical return remains almost entirely unimpaired, if not actually enhanced because of any perceived humiliation of the speaker.

92 Given the generalized content of the writer's diary, without any personal threats, it is difficult to see how the Tinker rights prong can achieve much. Of course, there is always the potential for the speaker to return to the school without authorization. The potential disruption such a return would cause no doubt weighs on students' minds to some degree. A typical student, for example, might well prefer not to be plagued by thoughts of a possible future Columbine-style attack. But it is unclear how to judicially address such anxieties in a free speech case beyond standard criminal, civil tort, and discrimination remedies, through something like the disruption or, on our theory, distraction inquiries already on the table.

93508 F.3d 765 (5th Cir. 2007). Instead of using Tinker, the Fifth Circuit formally decided Ponce under Morse v. Frederick, 127 S. Ct. 2618 (2007). The effect of the decision is similar, however.

94 Ponce, 508 F.3d at 766-67.

95 Id at 766 . 
high school. He predicts that this attack will occur on his high school graduation date, more than two years in the future. ${ }^{96}$

Ponce showed the notebook to a fellow student, who in turn told a teacher, who told an assistant principal about its offensive contents. The assistant principal called the writer into his office and reported receiving student complaints about the notebook, which the writer then voluntarily turned over to the assistant principal. ${ }^{97}$ Ultimately, the school determined that the writings "posed a 'terroristic threat' to the safety and security of the students and the campus." 98 The school suspended Ponce for three days and recommended that he be transferred to an alternative educational program, which ultimately occurred. ${ }^{99}$

The Fifth Circuit found no violation of Ponce's First Amendment rights. The court based its decision on an extension of Morse to speech threatening the physical safety of students. ${ }^{100}$ Morse had refused to apply Tinker's substantial disruption prong to drug speech. This refusal rested on the magnitude of the interest at stake - deterring drug abuse by schoolchildren was so important that speech advocating drug use was per se unprotected. Thus, school administrators need not evaluate the potential disruption from such speech under Tinker. The court turned to Justice Alito's concurrence to conclude that, like speech reasonably advocating drug use, the school has such a significant interest in preserving the physical safety of the students that Tinker does not protect speech that threatens violence.

As above, we may assume that there was in fact a likelihood of substantial disruption. But again, even if this assumption holds, there is little connection between the perceived severity of the threat and the administrative action in Ponce. As in LaVine, the decision to suspend the student - here only for three days - does not prevent his access to school and may in fact aggravate the threat. Even transferring the writer to another school does little to prevent the writer's direct physical access, at any chosen time and place, to the former school's administrators, teachers, or students. Nor does transferring the student protect the unspecified minority group members from violence outside of school. If Ponce were intent upon committing violence, he is unlikely to have been deterred by punishment for truancy from his new

\footnotetext{
96 Id.

97 Id.

98 Id. at 767

99 Id.

100 Id. at 770 .
} 
school. And of course, transferring him does not prevent him from posing a threat to his new classmates and teachers.

These realities make a distraction rationale more appealing and cause us to question a disruption rationale. A distraction rationale makes the administrative response seem more rational in light of the threat. As in LaVine, the student's suspension allows a return to normalcy without the student's presence, allowing teachers, students, and officials to immediately return to doing their jobs. And his transfer permanently removes the distraction from other students and the teacher who might constantly live in fear of a potential attack, even if unlikely. By contrast, were the school district genuinely concerned with substantial disruption, the approaches outlined above, including extensive monitoring, counseling, and testing seem more likely to neutralize the threat than does summary suspension and transfer.

The Ponce court may have implicitly accepted a distraction theory as justifying these administrative responses. Ponce applied Morse, not Tinker, in upholding the restriction on free speech. It found that Morse logically makes threats per se unprotected when they "gravely and uniquely threaten[] violence, including massive deaths, to the school population as a whole." ${ }^{01}$ In these circumstances, the administrator need not meet Tinker's requirement that the threat pose a risk of substantial disruption. This reasoning can be interpreted in multiple ways. It can mean that all threats of mass violence, no matter how improbable, pose a substantial disruption as a matter of law. Alternatively, it can mean that these threats, while not disruptive, are necessarily so distractive to the educational mission of the schools that the First Amendment must give way to administrators' ability to nip these threats in the bud.

In contrast to Ponce's approach, courts have generally applied Tinker's substantial disruption prong in adjudicating threats aimed at individuals, such as teachers. For example, in Boim v. Fulton County School District, the Eleventh Circuit applied this prong to find that the First Amendment did not protect a student notebook containing threats of violence aimed at her art teacher. ${ }^{102}$ In Boim, a high school student shared her notebook with a classmate during an art class. Noticing the distraction, the art teacher requested that she turn over the notebook. The student eventually complied with the request. The notebook contained a narrative, claimed later to be a fantasy devoid of

101 Id. at 771-72.

102494 F.3d 978, 982-83 (11th Cir. 2007). 
any political or public-interest content, in which the writer described shooting her art teacher during class. ${ }^{103}$ The writer admitted in the notebook to having no reason for hating her art teacher. ${ }^{104}$ Naturally, her teacher felt shocked, threatened, and uncomfortable. ${ }^{105}$ In response to the threat, the school principal suspended the writer for ten days. ${ }^{106}$ The Eleventh Circuit upheld the writer's ten-day suspension as justified under the Tinker disruption prong. ${ }^{107}$

As with LaVine and Ponce, the Eleventh Circuit's judgment makes more sense under a distraction rationale than under a disruption rationale. As above, we can assume that the student's threats were likely to pose a substantial disruption and that the administrative reactions were appropriate under the circumstances. But as in those cases, the administrative resolution to the problem - a ten-day suspension - is more justified by a distraction theory than a disruption theory. A ten-day suspension may at least allow the art teacher or the art class students to recover their bearings and allow emotional reactions to subside. In short, the suspension eliminates distractions from the task at hand. But as discussed above, in light of recent school shootings, this approach seems unlikely to prevent substantial disruption. ${ }^{108}$ Even if Morse is read to treat threats of physical violence per se as posing a substantial disruption to the school, the administrative response here lacks a strong connection to the supposed gravity of the student's threat. ${ }^{109}$

Again, if disruption is really the problem, a more integrative and less punitive approach might better serve the student's and the school's interests. A school may be better off clarifying the writer's state of mind - whether she actually intends to harm the teacher - through conversations with the student, guidance counselors, and parents. Of course, without closure or perhaps a security check, any subsequent class with the writer and the art teacher would likely pose some distraction. The important point, however, is a certain degree of distraction may justify infringement of student speech even if it does not arise to physical disruption, disorder, indiscipline, or disturbance.

\footnotetext{
103 Id. at $980-81$.

104 Id. at 980.

105 Id. at 981.

106 Id.

107 Id. at 981-82. A recommended expulsion was administratively rejected. Id. at 982.

108 See id. at 983-84.

109 See id. at 984 (citing Morse regarding illegal drug promotion speech and apparently finding threats of physical violence to be within scope of Morse logic).
} 
Finally, another recent case, Wisniewski v. Board of Education, ${ }^{110}$ also involved a threat aimed at the student's teacher. Unfortunately, it reaffirms the tendency for courts to overextend the Tinker disruption standard at the expense of inquiring into the extent of distraction. ${ }^{111}$ Wisniewski involved a middle school student's purported speech through the popular AOL Instant Messenger ("AIM") program. ${ }^{112}$ The student had created an icon to serve as his identifier on AIM. ${ }^{113}$ The icon was a small drawing of a pistol firing a bullet at a person's head, above which were dots representing spattered blood. ${ }^{114}$ Beneath the drawing appeared the words "Kill Mr. VanderMolen," the student's English teacher. ${ }^{115}$ After messaging with other students in the class, the icon came to the attention of Mr. VanderMolen. He felt distressed, despite the student's expressed regret. After a police investigation, psychological evaluation, and interviews with other students, the school suspended the student for five days. ${ }^{116}$ As a precautionary measure, it also excused the teacher from instructing the student's class for the remainder of the semester. ${ }^{117}$ Although the school allowed the student back into school pending a hearing, he was later suspended for a full semester. ${ }^{118}$

The Second Circuit affirmed the disciplinary decision on Tinker disruption grounds. ${ }^{119}$ The court first determined that the Supreme Court's decision in Tinker applied to threats of violence rather than its decision in Watts $v$. United States. It found that Tinker provided school officials with significantly broader authority to sanction student speech than the true threats standard under Watts. ${ }^{120}$ Next, even were the student's speech to express an opinion, the court agreed with administrators that this speech posed a reasonably foreseeable risk of material and substantial disruption and discipline within the school. ${ }^{121}$

\footnotetext{
110494 F.3d 34 (2d Cir. 2007).

111 Id. at 38-39.

112 Id. at 36.

113 Id. at 35-36.

114 Id. at 36.

115 Id.

116 Id.

117 Id.

118 Id. at 36-37.

119 Id. at 35, 38-39.

120 Id. at 38.

121 Id. at 38-39.
} 
Again, I do not question the court's ultimate judgment in the case but rather its rationale. As opposed to the other doubtful threats cases, the fact that the school had to request a police investigation, conduct a psychological evaluation, interview other pupils and find a replacement teacher all point to classic understandings of substantial disruption, if not disorder, physical disturbance, or indiscipline. ${ }^{122}$ Of course, these disruptions would have presumably occurred even in the case of an entirely innocent accused party. ${ }^{123}$ Thus, a distraction rubric is clearly preferable to explaining the administrative reaction once the threat was fully assessed and understood. Undoubtedly, even after the teacher was replaced, the student's new class and replacement teacher dealt with uncertainty and distraction throughout the remainder of the semester. And his ultimate suspension for an entire semester provided for all students in his grade and his teachers to avoid repeated distractions based on their knowledge and fear of his writings.

Thus, Wisniewski, like LaVine, Ponce, and Boim, most likely arrived at a sensible judgment in light of recent school violence. But its rationale, like the other cases, does not seem to fully justify the administrative action that it upholds. As I have shown, these actions are better understood under a distraction rationale. The next Part makes the case for this rationale and explains how to best achieve its incorporation into law.

\section{CONCENTRATING ON Distraction: AN UNDER-RECOGNIZED CONSIDERATION UNDER TINKER}

As the review of the cases in Part II makes clear, something more than a concern for disruption lies at the heart of the administrative responses to threats and the justifications courts give to those responses. In many instances, the problem is the distractive effects of threats in the school setting. As outlined in the introduction, distractions in the public-school setting involve diminished attention on the part of students, teachers, and administrators to their functional roles in a school. Students are distracted from their in-class assignments, from homework, or from fully participating in or enjoying playground activities. Teachers are diverted from the crucial task of educating students. Administrators, whose jobs consist, in part, of addressing the very problems threats pose, nevertheless must shift focus away from curricular development, teacher placement,

122 See id. at 36-37.

123 See id. 
budgetary analysis, and the myriad other functions they assume. While some distractions may be only momentary, and while momentary distractions are inevitable, other distractions are significant. These more significant forms of distraction are uniformly the result of other students' behavior and speech - they are not selfinduced by bored students. ${ }^{124}$ These significant distractions impose substantial costs on the educational process. What is more, the speech at issue, especially when it is nonpolitical, provides only a marginal benefit to the marketplace of ideas. As such, free speech rights under the First Amendment must give way to the compelling interest that schools and other students have in ensuring an educational experience free of significant distraction.

The relationship between distraction and disruption is evident. It is almost always the case that substantial disruption causes substantial distraction. Yet the reverse is not true. Substantial distraction may not arise to the level of substantial disruption. Thus, a bomb threat is likely to both cause substantial disruption at a school - evacuation of classrooms, cancellation of school, and police intervention - and to substantially distract students and teachers even after they return to school. But speech containing threats to commit violence at some unknown time in the future against unknown individuals, while not prompting the reactions to a bomb threat, nevertheless has significant distractive effects.

Thus, Tinker is well suited to handle the first category of threats, those posing both risks of substantial disruption and distraction. Consider, for example, the broad category of actual instances of physical violence within the schools. ${ }^{125}$ Presumably, such overt

124 See, e.g., Coy v. Bd. of Educ., 205 F. Supp. 2d 791, 795-96 (N.D. Ohio 2002) (disciplining student for accessing his personal website while doing school work in school's computer lab). In Coy, the student's inconspicuous accessing, without displaying the screen to other students, was properly analyzed under the Tinker disruption standard. See id. at 800.

125 For background information on violence within schools, see NAT'L CTR. FOR Educ. Statistics \& Bureau of Justice Statistics, Indicators of School Crime and SAFETY: 2007, at vii, available at http://nces.ed.gov/pubs2008/2008021.pdf (finding that in 2005, approximately six percent of students ages 12-18 reported fears of attack or harm at school); David M. Herszenhorn, Assaults On Teachers Are Increasing, Union Says, N.Y. TIMES, May 20, 2003, at B9 (reporting on 869 cases of student assaults on teachers in New York City public schools during 2003 school year); The New York Times on the Web: Learning Network, Student Violence in America's Schools, http://www.nytimes.com/learning/general/specials/schoolviolence (last visited Jan. 9, 2009). Nor are such incidents confined either to large cities, or to the United States. See, e.g., Tim Grant, Students' Assaults On Teachers Hit High in 2006, PitTsBURGH PosT- 
physical violence can be properly addressed as either devoid of speech or under Tinker's disruption prong if student free speech issues arise.

But Tinker is not well suited to address those substantial distractions that do not arise to the level of substantial disruption. The phenomenon of physical violence is complex. The threat of physical violence can cast a shadow beyond the occurrence of violence. A history of violence, whether localized or wide reaching, can affect present realities. ${ }^{126}$ A fear, shared or unshared, of personalized or even abstract future violence can involve substantial distraction. Even generalized anxiety, whether felt individually or pervading school culture, can have serious distractive effects, whether traceable to any particular incident or not. These effects may continue in the absence of any substantial disruption.

Moreover, these effects may continue in the absence of any violation of a widely recognized right. ${ }^{127}$ This is of course the second way in

GAZETTE, Mar. 5, 2007, available at www.post-gazette.com/pg/07064/766954-298.stm (reporting that students physically assaulted 179 teachers in Allegheny County schools while doing their jobs last year); Jonathan Milne \& Madeline Brettingham, Teachers at Risk as Violence Escalates, Times EduCATIONAL SuPPLEMENT, Feb. 23, 2007, at 3 (reporting increasing verbal and physical abuse of British school teachers, with one third of respondents having had to take time off work as result of such incidents).

126 See Grant, supra note 125.

127 The constitutionally sound and practically enforceable recognition of not merely a right to physical safety, but of a right to subjectively feel or perceive oneself to be genuinely safe and secure at school, seems at least for the moment problematic. See generally Town of Castle Rock, Colo. v. Gonzales, 545 U.S. 748, 759-61 (2005) (interpreting Colorado law as not creating enforceable personal entitlement to mandatory individual enforcement of domestic violence or abuse restraining order, especially given tradition of police discretion in enforcement given limited resources); DeShaney v. Winnebago County Dep't of Soc. Servs., 489 U.S. 189, 195 (1989) (holding substantive due process does not create enforceable legal right to affirmative state protection of life, liberty, or property); Harper v. Poway Unified Sch. Dist., 445 F.3d 1166, 1176 (9th Cir. 2006) (stating "[t]he courts have construed the First Amendment as applied to public schools in a manner that attempts to strike a balance between the free speech rights of students and the special need to maintain a safe, secure, and effective learning environment."), reh'g denied, 455 F.3d 1052 (9th Cir. 2006), vacated, 127 S. Ct. 1484 (2007); Porter v. Ascension Parish Sch. Bd., 393 F.3d 608, 611 (5th Cir. 2004) (finding necessity to balance "duty to provide a safe school with the constitutional rights of individual students"); Doe v. Pulaski County Special Sch. Dist., 306 F.3d 616, 633 (8th Cir. 2002) (Heaney, J., dissenting) (stating "[s]chool administrators have a duty to ensure that students are educated in a safe environment, and this safety may come at the cost of limited student speech rights"); Saxe v. State Coll. Area Sch. Dist., 240 F.3d 200, 217 (3d Cir. 2001) (recognizing without judicially validating compelling governmental interest in promoting at least objectively "safe" school environment). Unfortunately, the problem of distraction that is somehow related to a subjective concern for future violence extends well beyond 
which Tinker might otherwise address distractive effects. The law, through criminal and civil remedies for battery and assault, clearly extends rights to students who are subjected to actual physical violence or a fear of imminent violence. But many threats do not meet these standards. In the absence of any right to freedom from distraction, Tinker's rights prong cannot address the distractive effects problem.

Tinker's disruption prong may also be insensitive to the evidentiary problems that distractions pose. Distractions, unlike disruptions, are not always easily perceived. Generally, the more internal or psychological the student or teacher's reactions, the harder it will be to prove substantial disruption under Tinker. One's quite reasonable psychological reactions to any experience or circumstance may range from minimal to extreme, without any disorder or breakdown of institutional discipline. A student or teacher's classroom performance may be adversely affected in observable and unobservable ways, as may that of a broader school community. ${ }^{128}$ Thus, significant distractions may not be overt and observable in any direct sense. Teachers and administrators may learn of their existence and effects only through self-reporting, observation over time, or indirectly through deteriorating student's grades, decreasing attention in class, or lowering attendance. Thus Tinker presents an evidentiary problem for administrators: while distractive effects impose significant burdens, they may be harder to prove to courts ostensibly looking for evidence of substantial disruption.

Finally, the costs that distractions pose to the American public school system far outweigh any corresponding benefit from speech containing threats. Free speech has always been an expensive public good. Its costs have been justified by the benefits that a free marketplace of ideas has in revealing political truth. The First Amendment rests in large part on a principle that bad speech should not be suppressed; rather, it should be countered with good speech. Nevertheless, society and the law have always recognized that threats are at the outer reaches of speech protected under the First Amendment. To the extent a threat is motivated by animus against individuals, and does not in substance convey a political point of view, it provides little in the way of ideas to enrich the marketplace.

any broadly enforced right to current physical safety in the schools.

128 See, e.g., J.S. ex rel. H.S. v. Bethlehem Area Sch. Dist., 807 A.2d 847, 852 (Pa. 2002) (allowing medical leave for entire school year for allegedly threatening and derogatory student website about middle school teacher and principal). 
If the value of nonpolitical threats is in question, the costs of distractive effects are not. Administrative reactions to these threats eat up substantial time, energy, and resources. Students and teachers fall behind in their curricular requirements. But most importantly, students fail to realize their potential when threats of violence loom over the school setting. The First Amendment protects myriad ways for students who disagree with - indeed hate - other students or teachers to express those views. The costs of expressing those views in the form of threats of physical violence, however, are too much to bear in the school setting.

The idea that distractions are a constitutionally legitimate basis for restricting student speech is not a new one. Justice Black's dissenting opinion in Tinker explicitly recognized the distractive effects that the speech at issue caused:

There is also evidence that a teacher of mathematics had his lesson period practically 'wrecked' chiefly by disputes with Mary Beth Tinker, who wore her armband for her 'demonstration.' Even a casual reading of the record shows that this armband did divert students' minds from their regular lessons, and that talk, comments, etc., made John Tinker 'selfconscious' in attending school with his armband.... I think the record overwhelmingly shows that the armbands did exactly what the elected school officials and principals foresaw they would, that is, took the students' minds off their classwork and diverted them to thoughts about the highly emotional subject of the Vietnam war. ${ }^{129}$

What Justice Black speaks of is distraction in its most elemental form: students unable to focus on their assignments and teachers unable to keep students to the task at hand. In Justice Black's view, the schools had a strong interest in preventing these effects. ${ }^{130}$

In light of Tinker's inability to address the distractive effects of threats, and the evidentiary problems and substantial costs those threats pose, First Amendment jurisprudence cries out for a distraction analysis. One solution, suggested to some degree by the Fifth Circuit in Ponce, ${ }^{131}$ and by the Supreme Court in Morse ${ }^{132}$ would

129 Tinker v. Des Moines Indep. Cmty. Sch. Dist., 393 U.S. 503, 517-18 (1969) (Black, J., dissenting).

130 See id. at 518

131 See Ponce v. Socorro Indep. Sch. Dist., 508 F.3d 765, 771-72 (5th Cir. 2007).

132 See Morse v. Frederick, 127 S. Ct. 2618, 2625 (2007) (holding that schools may 
be to explicitly craft a series of categorical exceptions to Tinker's protective speech rules in areas subject to a zero-tolerance policy. Doubtful threats posing substantial distractions, as defined in this Article, would be one such exception. In this way, threats to physical safety of the student body would be analogized to drug-related speech threatening their physical safety. One could argue that postColumbine, a school should be entitled to adopt an absolute prohibition on any language threatening physical violence, without the school having to prove the reality of the threat or the substantiality of any likelihood of disruption. The theory would be that any more rigorous or narrowly tailored policy might be less effective, overall, in reducing instances of actual school violence.

The actual effectiveness of such a zero-tolerance policy toward doubtful threats is largely an empirical or predictive matter. A zerotolerance policy may in some instances backfire. ${ }^{133}$ A zero-tolerance policy will also have difficulty making genuine exceptions for unusual circumstances. ${ }^{134}$ If free speech law is to proceed down the path of gradually carving out perhaps several categorical exceptions ${ }^{135}$ from the

"restrict student speech at a school event[] when that speech is reasonably viewed as promoting illegal drug use").

133 Students might do better by having social and mentoring relationships at school strengthened, as opposed to facing official stigmatization and penalty-oriented isolation. School officials and courts might bear in mind how difficult adolescence is for most teenagers. See, e.g., Jean M. Twenge, Generation Me 108 (2006) ("In 2003, $16.9 \%$ of high school students admitted that they had seriously considered attempting suicide during the past year and most of those said they had made a plan about exactly how they would kill themselves."). For the classic discussion of our tendency to overestimate the future probability of Columbine-like events that are dramatic, salient, and easily recalled, see Amos Tversky \& Paul Kahneman, Judgment Under Uncertainty: Heuristics and Biases, in Judgment Under UnCertainty: Heuristics and Biases 3, 3-14 (Daniel Kahneman, Paul Slovic \& Amos Tversky eds., 1982).

134 In S.G. ex rel. A.G. v. Sayreville Board of Education, 333 F.3d 417 (3d Cir. 2003), the speaker, whose free speech claim did not prevail, was a five-year-old kindergarten student. Id. at 418. The speech occurred during a recess game of cops and robbers and consisted of the five-year-old speaker declaring: "I'm going to shoot you." Id. Within the previous week, the administration had, against a background of other verbal threats, adopted essentially a zero-tolerance policy toward oral or written references to violence or weapons and had widely publicized the policy among students and parents. Id. The age of the speaker and the lack of core political content of the speech played a role in the outcome. See id. at 422-23.

135 A broader question not addressed here is whether there will be significant differences between creating categorical exceptions from Tinker's substantial disruption requirement only on an incremental basis and a broader rule expanding on language in Fraser. See Bethel Sch. Dist. No. 403 v. Fraser, 478 U.S. 675, 685 (1986). But see Morse, 127 S. Ct. at 2636-37 (Alito, J., concurring) (rejecting as subject to 
originally broad Tinker substantial disruption rule, history as it then unfolds will judge the ultimate results. But by introducing a distraction rationale to free speech analysis, the Supreme Court would directly address the issues highlighted in the doubtful threats cases. Lower courts would be able to rightly justify administrative responses that are more in keeping with distractions than disruptions. Although in my view this is the best approach, it is not the only one. The next Part explores alternative approaches to dealing with doubtful threats cases.

\section{Distractions From Distraction: ALternative APPROACHES TO DOUBTFUl THREAT CASES}

Up until now, I have argued that a judicial focus on something like substantial distraction would often be more sensible than a focus on the Tinker substantial disruption standard. Whether or not one agrees with this assessment, however, one might still seek some approach superior to both in accommodating the doubtful threat cases. This Part explores the strengths and weaknesses of six alternatives and ultimately concludes that none is superior to a distraction-based rationale.

First, the Supreme Court could extend the scope of "disruption" under Tinker to encompass significant distractions. The Court could perhaps accomplish this by choosing to redefine disruption as any impairment of a school's basic missions and purposes. Redefining disruption in this way would at least preserve the formalism of a supposed attention to disruption. The problem with this approach is that a definition of disruption broad enough to encompass distraction is inherently subject to manipulability. ${ }^{136}$ While one school

dangerous abuse broader principle permitting censorship of any student speech that interferes with public schools' "educational mission").

136 See Morse, 127 S. Ct. at 2637 (Alito, J., concurring). Justice Alito was especially concerned with expansive definitions that incorporated a school's mission:

The opinion of the Court does not endorse the broad argument advanced by petitioners and the United States that the First Amendment permits public school officials to censor any student speech that interferes with a school's "educational mission." This argument can easily be manipulated in dangerous ways, and I would reject it before such abuse occurs. The "educational mission" of the public schools is defined by the elected and appointed public officials with authority over the schools and by the school administrators and faculty. As a result, some public schools have defined their educational missions as including the inculcation of whatever political and social views are held by the members of these groups.

Id. (citations omitted). 
administrator may use such a broad definition to stamp out threats, another may use it to intentionally suppress free speech. Thus, failing to address distractions directly grants administrators more power than necessary to address the problems that threats pose.

A second alternative is to extend Tinker's rights prong to hold that doubtful threats may violate the rights of others in the school setting, including students and teachers. ${ }^{137}$ Of course, we cannot generally say that substantially distracting speech will always violate some judicially enforceable right unless we are to assume that there is a right to freedom from substantial distraction itself. One might develop a theoretical case for such a right, based for example on other students' right to education or safety. Secondly, one might extend the Tinker rights prong by arguing in favor of an objective right to personal security. ${ }^{138}$ These alternatives might better explain administrative actions like suspension or transfer that preserve those students' rights than does a disruption rationale. Nevertheless, this seems like an unrealistic option given the difficulty in first creating and then defining these rights. Even if it were realistic, this theory does not substantively improve upon a concern for distraction as undermining the most essential functions of the public schools.

Related to this idea of rights violation under Tinker, a third alternative would be to extend the vague bounds set forth in Fraser ${ }^{139}$ to explain administrative responses to doubtful threats. ${ }^{140}$ Fraser permits schools to regulate speech that is lewd, vulgar, indecent, or plainly offensive, at least as to form as somehow distinct from content, political or otherwise. ${ }^{141}$ Generally, Fraser applies to speech in a school-sponsored or a captive student audience context. But Fraser has sometimes been interpreted broadly to encompass any speech

137 See supra notes 65, 124 and accompanying text.

138 Such a right would be contrasted to a subjective right to personal security, whereby the victim would have her rights infringed if she subjectively felt insecure in her person.

139 See Fraser, 478 U.S. at 683-85.

140 See, e.g., Chandler v. McMinnville Sch. Dist., 978 F.2d 524, 529 (9th Cir. 1992) (linking language found regulable in Fraser with violation of rights of other students).

141 See Morse 127 S. Ct. at 2626; Guiles v. Marineau, 461 F.3d 320, 327-28 (2d Cir. 2006); Saxe v. State Coll. Area Sch. Dist., 240 F.3d 200, 213 (3d Cir. 2001) (Alito, J., for the court); Chandler, 978 F.2d at 524; DePinto v. Bayonne Bd. of Educ., 514 F. Supp. 2d 633, 638 \& n.1 (D.N.J. 2007) (discussing Morse's lack of clarity on scope and rationale of Fraser). In DePinto, the district court found that the use of Hitler Youth photographs in a protest against school uniform policy was not "plainly offensive." DePinto, 514 F. Supp. 2d at 645. 
deemed inconsistent with the school's "basic educational mission." 142 Fraser is, however, most naturally read to apply to sexually laden speech. The student speech at issue in the case was an election speech filled with sexual innuendo. Thus, while doubtful threats may be indecent or plainly offensive in the broadest sense of those words, they often are not lewd or vulgar. ${ }^{143}$ Moreover, speech can be distracting to some degree without also being within any reasonable or literal definition of indecent or plainly offensive.

A fourth alternative would be to forge a special free speech rule focusing on physical safety and threats to physical safety of public school students. ${ }^{144}$ In Morse, Justice Alito notes that students may face dangers in school that are more readily avoided outside of school, ${ }^{145}$ and that students may also be limited in their ability to protect themselves in school. ${ }^{146}$ No doubt many overt threats to safety will also be distracting. ${ }^{147}$ Unfortunately, this is also of limited assistance to explaining doubtful threats cases. If these threats truly present danger to physical safety, the administrative responses seem inadequate. Furthermore, speech can cause almost any degree of distraction without endangering anyone's physical safety in the least.

A fifth approach to the doubtful threat cases would involve narrowing the scope of Tinker's speech protective dimension through application of the forum doctrine. The Seventh Circuit, notably in Muller ex rel. Muller $v$. Jefferson Lighthouse School, ${ }^{148}$ has arguably taken this tack. Muller has been interpreted as implying that student speech cases should not begin with a presumption that Tinker protection applies, but with a determination of whether or what type

142 See Boroff v. Van Wert City Bd. of Educ., 220 F.3d 465, 470 (6th Cir. 2000). But see Guiles, 461 F.3d at 329; Newsom ex rel. Newsom v. Albemarle County Sch. Bd., 354 F.3d 249, 256 (4th Cir. 2003). It is also instructive to focus on the Court's uncertainty in Morse. Morse, 127 S. Ct. at 2626.

143 See Guiles, 461 F.3d at 328 (arguing that even 'plain offensiveness' in this context may require some sort of sexual overtone).

144 See Morse, 127 S. Ct. at 2638 (Alito, J., concurring).

145 Id.

146 Id.

147 See Layshock v. Hermitage Sch. Dist., 496 F. Supp. 2d 587 (W.D. Pa. 2007); supra note 75 .

14898 F.3d 1530 (7th Cir. 1996). In a somewhat similarly restrictive spirit, see generally Brandt v. Board of Education, 480 F.3d 460 (7th Cir. 2007) (Posner, J.) (rejecting free speech claim by eighth graders wearing protest T-shirts regarding school referendum on T-shirt design). See Brandt, 480 F.3d at 466 (discussing Muller); Griggs v. Fort Wayne Sch. Bd., 359 F. Supp. 2d 731, 740 (N.D. Ind. 2005). 
of public forum the student speech occurred in. ${ }^{149}$ Under this approach, where the speech occurrs outside of a public forum, ${ }^{150}$ the threshold for restricting speech is minimal. ${ }^{151}$

Whatever one thinks of the Muller approach, its applicability to the doubtful threat cases seems limited. ${ }^{152}$ Much of the speech in such cases takes place in privately owned notebooks, websites, or chat rooms that are accessible outside of any school or its property. The doubtful threat speech certainly need not take place within the school and in a nonpublic forum. ${ }^{153}$ Ultimately, it is difficult to believe that in order to assess the speech rights involved, say, in an informal encounter between a teacher and a student after class, the focus should be on the character of the forum involved, if any, and not more directly on the various pedagogical, speech, privacy, security, and public interest values that may be at stake. A distraction analysis of course considers these interests directly.

A sixth and final alternative would be to bypass the distraction analysis in the doubtful threat cases by classifying speech regulations in such cases as content neutral rather than as content based. ${ }^{154}$ This theory begins by noting that the prohibition of the armbands in Tinker was presumably based on the content, if not the viewpoint, of the symbolic speech in question. ${ }^{155}$ Whether Tinker should be read to apply to not only viewpoint- or content-based regulations, but also to contentneutral regulations of speech is unclear. On this point, the Morse

149 See Muller, 98 F.3d at 1537-39.

150 See id. at 1537-38; Griggs, 359 F. Supp. 2d at 740. For discussion of public forum doctrine and types of forums in the student speech context, see generally Wright, School-Sponsored Speech, supra note 59. For school-based discussion of public forums, the leading case is Perry Education Ass'n v. Perry Local Educators' Ass'n, 460 U.S. 37, 45-46 (1983).

151 See Muller, 98 F.3d at 1537-39 (referring to nonpublic forum and rational relationship to any legitimate pedagogical concern speech test in Hazelwood, 484 U.S. at 270-71). Whether speech restrictions under Hazelwood must also be viewpoint neutral has divided the circuits. See Chiras v. Miller, 432 F.3d 606, 615 n.27 (5th Cir. 2005) (discussing decisions on question of whether speech restrictions under Hazelwood must be viewpoint neutral).

152 For a sense of the minority status of Muller in certain applications, see Griggs, 359 F. Supp. 2d at 741.

153 For some authoritative language, see Hazelwood School District v. Kuhlmeier, 484 U.S. 260, 270-76 (1988).

154 For a discussion of the basic distinction with a sense of the limits of its utility, see Wright, supra note 14 , at 337-39.

155 See Tinker v. Des Moines Indep. Cmty. Sch. Dist., 393 U.S. 503, 509 (1969). 
opinion is not definitive, ${ }^{156}$ and the circuit courts are currently divided. ${ }^{157}$ Thus, if administrative responses to doubtful threats are viewed as aiming to curb the harmful effects of the speech, rather than silence the speaker's viewpoint or subject matter, perhaps such an approach would justify the administrative responses to doubtful threats.

But if we assume that a more speech-restrictive test, and not Tinker, applies to content-neutral regulations of doubtful threats, we face a substantial problem. The regulations in the case law governing most if not all of the doubtful threat cases discussed above ${ }^{158}$ are content based. ${ }^{159}$ Generally, speech regulation that makes necessary and crucial reference to audience members' cognitive and emotional assessment and mental processing of the content or message of the speech, including reactions of fear or anxiety, belief or disbelief, and all similar reactions, must be considered as content based. ${ }^{160}$

156 Understandably, the opinion in Morse refers to Tinker as applying to restrictions on student speech implicitly, generally, and also to viewpoint-based restrictions of student speech in particular. See Morse v. Frederick, 127 S. Ct. 2618, 2626, 2629 (2007).

157 See, e.g., Pinard v. Clatskanie Sch. Dist. 6J, 467 F.3d 755, 759 n.1 (9th Cir. 2006) (declining to apply content-neutral speech restriction test of United States v. O'Brien, 391 U.S. 367, 377 (1968), as opposed to Tinker). In Pinard, however, the Ninth Circuit recognized the Fifth Circuit as applying the O'Brien content-neutral restriction test in mandatory school uniform cases. See Pinard, 467 F.3d at 759 n.1 (citing Littlefield v. Forney Indep. Sch. Dist., 268 F.3d 275 (5th Cir. 2001); Canady v. Bossier Parish Sch. Bd., 240 F.3d 437, 443 (5th Cir. 2001)). Pinard also stands for the related, and perhaps also reasonably disputable, proposition that the scope of Tinker's more rigorous speech restriction test also extends to speech, unlike that actually at issue in Tinker, that is without political content, or is addressed to personal matters not rising to the level of public interest or concern. See id. at 765-66 ("[N]either Tinker nor its progeny limited students' rights solely to the exercise of political speech or speech that touches on a matter of public concern.").

For further discussion of the Fifth Circuit's reliance on O'Brien rather than Tinker in cases involving content-neutral restriction of student speech, see Porter v. Ascension Parish School Board, 393 F.3d 608, 615 (5th Cir. 2004) (citing Canady, 240 F.3d 437). For a similar analysis from the Sixth Circuit, see Blau v. Fort Thomas Public School District, 401 F.3d 381, 391 (6th Cir. 2005). For recognition of the current lack of clarity as to whether Tinker's protective standard extends beyond political speech or political viewpoint discrimination, see Guiles v. Marineau, 461 F.3d 320, 326 (2d Cir. 2006). The Second Circuit in Guiles ultimately opted for the broader, more encompassing reading of Tinker. See id.

158 See supra Part IV.

159 For a useful discussion, see Saxe v. State College Area School District, 240 F.3d 200, 209 (3d Cir. 2001).

160 See id. (citing Forsyth County v. Nationalist Movement, 505 U.S. 123, 134 (1992) (stating "[l]isteners' reaction to speech is not a content-neutral basis for regulation")); see also Boos v. Barry, 485 U.S. 312, 321 (1988) (similar). 
Nor is it plausible to pretend that administrators are regulating doubtful threats on some genuinely content-neutral basis, as though the problem were analogous to one of litter in the streets ${ }^{161}$ or excessive sound volume. ${ }^{162}$ Thus, applying a content-neutral test to the restriction of doubtful threats in the public school context would, at a minimum, leave loose ends to tie up. How, for example, is a court to distinguish between restrictions intended to address the effects of speech and those intended to suppress the very speech itself? Moreover, those courts that appear to favor a demanding Tinker standard even for content-neutral restrictions of student speech ${ }^{163}$ would have explaining to do. Why should content-neutral restrictions of student speech face the Tinker standard while content-neutral restrictions of speech even by adults, on political subjects or in public parks, be subject to less scrutiny than Tinker? ${ }^{164}$ Perhaps such a case could be made, given the various basic missions of the public schools, including training and practice in free speech. ${ }^{165}$ We need not evaluate or resolve that question here. Rather, this exercise shows the doctrinal problems and inconsistencies of trying to fit distractions into current frameworks. The preferable solution, then, is to expressly adopt a distractive analysis, thereby promoting clarity in an already confusing and unclear area of constitutional law.

\section{CONCLUSION}

Throughout, this Article has left unquestioned every court's determination that the doubtful threat in question was sufficiently concrete and probable to qualify under the Tinker substantial disruption standard. But if we set aside this deference for a moment, we see that many of these cases involve threats that are no more disruptive than the armbands in Tinker itself. Yet if that is true, it means that courts today are applying Tinker in a dramatically different

161 See, e.g., Schneider v. New Jersey, 308 U.S. 147 (1939) (noting First Amendment does not preclude outlawing littering, even of pamphlets).

162 See, e.g., Ward v. Rock Against Racism, 491 U.S. 781 (1989) (upholding soundamplification guidelines); Kovacs v. Cooper, 336 U.S. 77 (1949) (upholding bans on "sound trucks").

163 See Pinard v. Clatskanie Sch. Dist. 6J, 467 F.3d 755 (9th Cir. 2006); Guiles v. Marineau, 461 F.3d 320, 327-28 (2d Cir. 2006).

164 See, e.g., Morgan v. Plano Indep. Sch. Dist., 2007 WL 397494, at*8 (E.D. Tex. 2007) (comparing content-neutral analysis with Tinker standard).

165 See supra notes 1-6 and accompanying text. 
way. Transparency demands that we recognize this shift. Accepting a distraction rationale would do just that.

A genuine application of Tinker suggests many doubtful threats are unlikely to pose a substantial disruption. The Tinker standard is intended to distinguish between two types of administrative fears: legitimate fears that speech is likely to pose a substantial disruption and illegitimate fears that are merely a vague, undifferentiated, speculative apprehension of disorder. ${ }^{166}$ In the doubtful threat cases, we do at least have specific persons, the speakers themselves, who are thought to be the possible agents of disruption. But the improbability that these threats will be carried out often makes administrative fears speculative. We should remember that Tinker also involved speakers who were specifically identifiable in advance and who evinced a clear intent to carry out their plan. ${ }^{167}$

Moreover, the doubtful threats cases may be no more disruptive than the speech at issue in Tinker itself. The Vietnam War provoked emotionally charged debates over an issue of life and death importance, and with a strongly felt personal dimension for many. Thus, it would hardly have been absurd for a school to imagine, say, the sort of tense confrontations leading to physical altercations that have elsewhere been found to qualify as substantial disruptions. ${ }^{168}$ Physical altercations based on Vietnam War policy outside the schools were not uncommon. ${ }^{169}$

Therefore, the realistic differences between the doubtful threats often found substantially disruptive today and the actual circumstances in Tinker held insufficiently disruptive are not substantial. This suggests that in the post-Columbine era, the meaning and rigor of the Tinker disruption standard has in practice significantly changed, even if the test remains formally unchanged. This shift in substance may or may not be justified. Either way, however, we are better off explicitly admitting such a judicial shift. Transparency and candor require no less. We do not, under a system of democratic self-government, pretend, for example, that the rules of airport security today are the same rules of twenty years ago. We

\footnotetext{
166 See Tinker v. Des Moines Indep. Cmty. Sch. Dist., 393 U.S. 503, 508 (1969).

167 See id. at 504 (noting that group of adults and students, including Tinkers, held meeting to plan armband protest and school was aware of this meeting).

168 See Wright, Dignity and Conflict, supra note 59, at 569-74; Wright, SchoolSponsored Speech, supra note 59, at 202 n.160.

169 For a similar verbal incident addressed by the Court, see Gooding v. Wilson, 405 U.S. 518, 520 (1972).
} 
acknowledge significant policy change, for the sake of meaningful debate on the merits of the changes.

This Article has argued that a shift of focus to distraction over disruption would achieve this transparency. In many contexts, both in doubtful threat cases and beyond, the judicial focus need not be on the likelihood of disruption in the Tinker sense. Distraction is real in the sense that administrators can readily testify to its effects and predict it with far less speculation. Furthermore, substantial distraction can be no less inimical to the school's essential missions and purposes than disruption, especially given lingering distractive effects. Distraction, rather than disruption, gets closer to explaining the real nature of the educational harms that doubtful threats pose in modern American public schools. 